\title{
Effect of Gender on Senior Secondary Chemistry Students' Achievement in Stoichiometry Using Hands-on Activities
}

\author{
Oluwatosin Victor Ajayi ${ }^{*}$, Josiah Ogbeba \\ Department of Curriculum and Teaching, Benue State University, Makurdi, Nigeria \\ *Corresponding author: drvictorajayi@gmail.com
}

\begin{abstract}
The study examined the effect of gender on students' achievement in stoichiometry using hands-on activities. A sample of 292 students from eight purposively selected secondary schools out of a population of 8,381 SS II students from zone C of Benue State, Nigeria was used for the study. The study adopted a quasi-experimental research design. Stoichiometry Achievement Test (SAT) was used for data collection. Reliability coefficient of 0.92 was established using Pearson correlation moment coefficient. Two research questions and two hypotheses guided the study. The research questions were answered using mean and standard deviation while the hypotheses were tested at 0.05 level of significance using Analysis of covariance (ANCOVA). The study revealed that there is no significant difference in the mean achievement scores between male and female students taught stoichiometry using hands-on activities; $(F(1,145)=4.160, p>0.05)$. It also found no significant interaction effect between methods and gender on the mean achievement scores of students in stoichiometry; $(F(1,291)=0.11, p>0.05)$. It was recommended among others that since hands-on activities method is not gender sensitive therefore both male and female students should be involved in hands-on activities to enhance their achievement in stoichiometry.
\end{abstract}

Keywords: hands-on activities, gender, achievement, stoichiometry

Cite This Article: Oluwatosin Victor Ajayi, and Josiah Ogbeba, "Effect of Gender on Senior Secondary Chemistry Students' Achievement in Stoichiometry Using Hands-on Activities." American Journal of Educational Research, vol. 5, no. 8 (2017): 839-842. doi: 10.12691/education-5-8-1.

\section{Introduction}

The development of any nation depends largely on the level of education attained by her citizens especially in the area of science and technology. Education is an instrument "par excellence" for effective national development [14]. It is highly rated as the most important instrument of change since any definite change in the intellectual and social outlook of the people must be preceded by an educational revolution [11]. In cognizance with the importance of science and technological in Nigeria, science subjects such as chemistry are taught in secondary schools to prepare a base for any science and technological development [6]. Chemistry is an experimental science that systematically studies the composition, properties, and activities of organic and inorganic substances and various elementary forms of matter [17]. However, the West African Examination Council (WAEC) Chief Examiners report [21] on Chemistry results indicates that students are weak in stoichiometry concepts in the Senior Secondary School Certificate (SSCE) Chemistry syllabus. The WAEC Chief Examiner's attributed the poor achievement of students due to their unfamiliarity with the use of simple laboratory equipment, inadequate exposure to laboratory techniques, lack of observational skills, omission of units in calculated values, inability to write chemical equation correctly, assign correct charges to ions as well as inability to carry out simple calculations among others.

Adegoke [4] reported that several researchers such as Aliu [6], Olorunyomi [16] and Olorundare [15] investigated the causes of students' poor achievement in SSCE physical Chemistry concepts and the most recurring factor is inefficient teaching methods such as demonstration, discussion, and lecture teaching methods employed by secondary school Chemistry teachers. Similarly, Olorunyomi [16] noted that demonstration method is popular in teaching SSCE physical Chemistry concept such as Stoichiometry. The researcher added that demonstration method is teacher-centered as it does not involve the learners enough participation. Functional education which deemphasizes mere regurgitation of facts and theories but internalization of concrete activities learnt that could be applied in any given situation. By implication, concrete activities learnt are activities which involve doing using apparatus. These includes weighing, measuring, demonstrating, carrying out tests/experiments and any other activities that could enhance students' achievement in such concepts such as stoichiometry taught conventionally in senior secondary schools.

Tile [19] describes hands-on activities as a situation whereby a learner uses his/her hands in carrying out activities that could enhance his/her experiences. Therefore, enhance his/her achievement in such concepts. 
By implication, concrete activities experiences are activities which involve doing using apparatus that could enhance students' achievement in such concepts such as Stoichiometry. Henry [13] describes Stoichiometry as an aspect of Chemistry that deals with calculations about the masses, or volume of reactants and products involved in a chemical reaction. The author added that, in a given a chemical reaction, Stoichiometry tells us what quantity of each reactant we need in order to get enough of our desired product(s).

Various interpretations or definitions have been given to hands-on activities by various scholars. In this study, it is defined as any activity that allows the learner to handle or manipulate a scientific process. In hands-on activities, learners interact with materials and equipment. Hands-on activities may also be defined as a variety of activities that may or may not be actual experiments such as observation or measurements, not necessarily carried out in laboratories. Abudullai [3] also describes hands-on activities as a method of teaching whereby students are engaged actively in class activities with the use of their hands and intellect under the guidance of the teacher. The differences between boys and girls in relation to chemistry education achievement have received a lot of attention in recent years.

Some studies indicate that boys achieve better (Gipps [12]), either no difference (Ventura [20]; Ajayi, [5]) or girls outperform boys (Calsambis [19]; Soyibo [18]) have been demonstrated. Studies on gender differences in chemistry achievement continue to yield inconsistence results and it has usually been attributed to unequal exposure of males and females to learning instructions relevant to chemistry learning. Treatment interaction according to Abonyi [2] generally implies that different learners with different characteristics may profit more from one type of instructional method than from another and that therefore it may be possible to find the best match of learners' characteristic and instructional method in other to maximize learning outcomes. The purpose of this study was to examine the effect of gender on senior secondary chemistry students' achievement in stoichiometry using hands-on activities. Specifically, the study:

1. Ascertained the difference in effect of hands-on activities between male and female students achievement in Stoichiometry.

2. Determined the interaction effect between methods and gender on students' achievement in Stoichiometry.

\subsection{Research Questions}

The following research questions guided this study:

1. What is the difference in the mean achievement scores between male and female students taught Stoichiometry using hands-on activities?

2. What is the interaction effect between methods and gender on students mean achievement scores in Stoichiometry?

\subsection{Hypotheses}

The following null hypotheses were tested at 0.05 level of significance:
1. There is no significant difference in the mean achievement scores between male and female students taught Stoichiometry using hands-on activities.

2. The interaction effect between methods and gender on the mean achievement scores of students in Stoichiometry is not significant

\section{Methodology}

The purpose of the research was to examine the effect of gender on chemistry students' achievement in stoichiometry using hands-on activities. The study used pre-test, post-test quasi experimental design. The study area was zone $\mathrm{C}$ of Benue State, Nigeria. The population of the study comprised all the 8,381 SSII students in the 136 granted aided schools. 158 male and 134 female students were purposively sampled from 8 schools that had some basic facilities and equipment in their laboratories. The experimental group was taught Stoichiometry using hands-on activities in line with lessons procedure prepared by the researcher while the control group was taught Stoichiometry using the demonstration lesson notes. An instrument known as Stoichiometry Achievement Test (SAT) developed by the researchers and validated by two experts from science education from Benue State University, Makurdi and one other from measurement and evaluation from University of Agriculture, Makurdi was used to collect the data. SAT contained two sections. Section "A" contained demographic information of the respondents, while section "B" contained a 30-item questionnaire to which respondents are expected to provide the correct answer by completing the gaps. After analyzing the data collected, SAT yielded a reliability coefficient of 0.92 using Pearson Correlation Moment Coefficient.

\section{Results and Tables}

\subsection{Research Question One}

What is the difference in the mean achievement scores between male and female students taught Stoichiometry using hands-on activities? The answer to research question one is contained in Table 1.

Table 1 revealed that the mean difference of both sexes was 0.24 . This difference though small is in favour of the male students. This implies that male students achieved slightly higher than their female counterparts in Stoichiometry using hands-on activities.

\subsection{Research Question Two}

What is the interaction effect between methods and gender on students mean achievement scores in Stoichiometry? The answer to research question two is presented in Table 2.

The results in Table 2 revealed that, the mean achievement scores of male students taught stoichiometry 
using hands-on activities and demonstration method are 24.47 and 16.23 respectively while the mean achievement scores of female students taught stoichiometry using hands-on activities and demonstration method are 23.88 and 15.10 respectively. This shows that hands-on activities teaching method is superior to demonstration method at the two level of gender.

\subsection{Hypothesis One}

There is no significant difference in the mean achievement scores between male and female students taught Stoichiometry using hands -on activities. The answer to hypothesis one is presented in Table 3.

ANCOVA Test results in Table 3 reveal that there is no significant difference between the mean achievement of male and female students taught Stoichiometry using hands-on activities $(F(1,145)=4.160, P>0.050)$. The null hypothesis is therefore not rejected. This means that hands-on activities enhanced both male and female students' achievement in Stoichiometry.

\subsection{Hypothesis Two}

The interaction effect between methods and gender on the mean achievement scores of students in stoichiometry is not significant. The answer to hypothesis two is presented in Table 4.

ANCOVA test results in Table 4 revealed that the interaction effect between methods and gender on the mean achievement scores of students in Stoichiometry is not significant $(F(1,291)=.011, \quad P>0.050)$. The null hypothesis is therefore not rejected. This means that there is no need for separation of instructional method for male and female students since hands-on activities method should be used successfully for the two groups.

Table 1. Mean Achievement and Standard Deviation Scores of Male and Female Students taught Stoichiometry using Hands-on activities

\begin{tabular}{ccccccc}
\hline $\begin{array}{c}\text { Hands-on activities } \\
\text { Group }\end{array}$ & $\mathrm{N}$ & \multicolumn{2}{c}{ PRE-TEST } & & POST-TEST \\
\hline Male & 77 & 10.60 & 1.11 & 24.47 & 1.77 \\
Female & 69 & 10.25 & 1.69 & 23.88 & 1.61 & 0.59 \\
Mean difference & & 0.35 & & 0.24 & \\
\hline
\end{tabular}

Table 2. Mean and Standard Deviation Scores of Interaction Effect between Methods and Gender on Students' Achievement in Stoichiometry

\begin{tabular}{|c|c|c|c|c|}
\hline Gender & Method & $\mathrm{N}$ & \multicolumn{2}{|c|}{ POST-TEST } \\
\hline \multirow[t]{2}{*}{ Male } & Hands-on activities & 77 & 24.47 & 1.77 \\
\hline & Demonstration & 81 & 16.23 & 1.89 \\
\hline \multirow[t]{2}{*}{ Female } & Hands-on activities & 69 & 23.88 & 1.61 \\
\hline & Demonstration & 65 & 15.10 & 1.73 \\
\hline
\end{tabular}

Table 3. ANCOVA Test for Mean Achievement Scores of Male and Female Students taught Stoichiometry using Hands-on activities

\begin{tabular}{|c|c|c|c|c|c|}
\hline Source & Type III sum of square & & Mean Square & $F$ & Sig \\
\hline Corrected model & $1014.434 \mathrm{a}$ & 2 & 407.217 & 102.108 & .000 \\
\hline Intercept & 1336.755 & 1 & 1336.755 & 390.385 & .000 \\
\hline Pre-test & 211.098 & 1 & 211.098 & 67.876 & .000 \\
\hline Gender & 14.244 & 1 & 14.244 & 4.160 & .064 \\
\hline Error & 558.144 & 143 & 3.424 & & \\
\hline Total & 75044.000 & 146 & & & \\
\hline Corrected Total & $\mathbf{5 7 2 . 5 7 8}$ & 145 & & & \\
\hline
\end{tabular}

a. R squared $=.025$ (Adjusted R Squared $=.013$ ).

Table 4. ANCOVA Tests for Interaction Effect between Methods and Gender on Students' Achievement in Stoichiometry

\begin{tabular}{llccc}
\hline Source & Type III sum of square & & Mean Square & Sig \\
\hline Corrected model & $2067.954 \mathrm{a}$ & 2 & 429.977 & .000 \\
Intercept & 1525.111 & 1 & 1525.111 & .05 .115 \\
Pre-test & 221.371 & 1 & 221.371 & .000 \\
Methods*Gender & .034 & 1 & .034 & .011 \\
Error & 901.361 & 289 & 2.239 & .317 \\
Total & $\mathbf{1 1 9 3 6 4 . 0 0 0}$ & $\mathbf{2 9 2}$ & & \\
Corrected Total & $\mathbf{2 9 0 1 . 2 9 3}$ & $\mathbf{2 9 1}$ & & \\
\hline
\end{tabular}

a. $\mathrm{R}$ squared $=.434$ (Adjusted R Squared $=.427$ ). 


\section{Discussion}

The study examined the effect of gender on chemistry students' achievement in stoichiometry using hands-on activities. The findings of this study revealed that male

students achieved slightly higher scores than their female counterparts using hands-on activities but ANCOVA test shows that the difference was not significant. This finding agrees with the findings of Eze [10] and Al-Mustapha [8] who found that there was no significant statistical

difference between the achievement of male and female students in Chemistry. Based on this finding, achievement in science is therefore not dependent on gender. This means that the age long disparity in science between male and female students can be laid to rest with the use of

hands-on activities. However, this finding contradicts the finding of Abe [1] who found gender disparity in students' achievement in favour of female in basic science and

technology. The finding of this study also revealed that

there is no significant interaction effect between methods and gender on mean achievement scores of students in

Stoichiometry. It shows that hands-on activities instructional method is superior to the demonstration method irrespective of gender in fostering achievement. In

this case, there is no need for separation of instructional method for male and female since hands-on activities method should be used successfully for the two groups.

\section{Conclusion}

It is evident from the findings of this study that no gender disparity exists in the achievement of male and

female chemistry students taught stoichiometry using hands-on activities. This implies that hands-on activities method is very rewarding for students' in-terms of achievement regardless of their gender.

\section{Recommendations}

1. Hands-on activities method is not gender sensitive; therefore, both male and female students should be involved in hands-on activities to enhance their achievement in Stoichiometry.

2. Workshops, conferences or seminars should be organized by Ministry of Education and other

school administrators on the need for hands-on activities in the teaching of Stoichiometry in order to enhance both male and female students' achievement. achievement and retention in Geometry. Unpublished Ph.D Thesis,

[2] Abonyi, S. T. (2014). Effect of experiential approach on students'

Lagos State University, Lagos State.

[3] Abudullai, A. A. (2013). Teachers' involvement in the use of hand-on laboratory methods in teaching. International Journal of Education, 3(11), 234-237.

[4] Adegoke, F. A. (2013). Teaching for Nigerian secondary schools modern strategies in the teaching of Chemistry. Ibadan: Powerhouse Press Publisher.

[5] Ajayi, O.V. (2016). Effect of hands-on activities on senior secondary chemistry students' achievement and retention in stoichiometry in Zone C of Benue State. Unpublished M.Ed

dissertation, Benue State University, Makurdi.

[6] Akinsola, N. (2011). Education and Science, Technology. Journal of Research in Science Teaching, 10(2), 12-16.

[7] Aliu, A. A. (2011). Effect of concept mapping approach on students' achievement and retention in electrolysis. Unpublished M.Ed Dissertation, Lagos State University, Lagos State.

[8] Al-Mustapha, A. (2014). Relationship of practical work on the achievement of students' in Chemistry in Kebbi State. Unpublished M.Ed dissertation, Kebbi State University of Science and Technology, Aliero.

[9] Calsambis, S. (2007). Gender related differences in acquisition of formal reasoning schemata: pedagogic implication of teaching science using inquiry based approach. International Journal of Education, 23(1), 435-440.

[10] Eze, S. (2010). Effect of practical knowledge of Chemistry as predictors of students' performance in theoretical aspect of Chemistry. Unpublished PhD thesis, University of Nigeria,

Nsukka.

[11] Ezeugo, N.C. (2009). Effect of concept mapping on students' achievement and interest in Algebra. Unpublished M.Ed dissertation, University of Nigeria, Nsukka.

[12] Gipps, K. S. (2004). Gender inequality. In Therney, H. (Ed.) Women's Studies Encyclopedia. New Yolk: Peter Bedrick Books.

[13] Henry, K. Y. (2007). Basic Stoichiometry. Retrieved on 13th February, 2015 from http://www.psych.stanford.edu/Stoichiometry/parin.pdf

[14] Ocho, L. O. (2005). National development and the curriculum in Oriaifo, S.O. Edozie, G.C.; \& Ezeh, D.N. (eds.), Curriculum issues in contemporary Education. Benin City: Da Sylra.

[15] Olorundare, A. S. (2014). Correlates of poor academic performance of secondary school students in the sciences in Nigeria. Paper presented at the International Institute for Capacity Building in Higher Education, Virginia State University, Virginia, USA. 20th -31 st June, 2014.

[16] Olorunyomi, A. A. (2013). Effect of experiential teaching method on students' achievement in Chemistry. Unpublished M.Ed dissertation, Ekiti State University, Ado Ekiti.

[17] Senese, F. (2010). Introduction to chemistry. Retrieved on 13th

July, 2016 from http://www.antoine.frostburg.edu/chem.pdf
[18] Soyibo, K. (2009). Gender differences in Caribean students' performance on a test of errors in Biology lebelling. Research in Science and Technological Education, 17(1), 75-82.

[19] Tile, M. T. (2013). Effect of activity-based on psychomotor skills acquisition and interest of senior secondary 2 in Biology. Unpublished M.Ed Dissertation. Benue State University, Makurdi.

[20] Ventura, F. (2008). Gender, science choice and achievement: A maltese perspective. International Journal of Science Education, 14(4), 445-461.

[21] WAEC (2015). Chief Examiner's reports for May/June WASSCE. Lagos: WAEC.

\section{References}

[1] Abe, T. S. (2011). Effect of field-trip on students' achievement and retention in Basic Science in Ikere Ekiti Local Government Area of Ekiti State. Unpublished Master dissertation, Ekiti State University, Ado Ekiti. 